\title{
Juvenile hyaline fibromatosis: A 47-year follow-up
}

\author{
Imad L Kaddoura MD FACS ${ }^{1}$, Amjad A Mufarrij MD ${ }^{2}$ \\ ${ }^{1}$ Division of Plastic \& Reconstructive Surgery, Department of Surgery and ${ }^{2}$ Department of Pathology \\ and Laboratory Medicine, American University Medical Center, Beirut, Lebanon
}

\section{IL Kaddoura, AA Mufarrij. Juvenile hyaline fibromatosis: A 47-year follow-up. Can J Plast Surg 1999;7(3):123-128.}

Approximately 40 cases of juvenile hyaline fibromatosis have been reported to date. This condition has not previously been described in the plastic surgery literature. This report describes a case where the disease led to a complete nasal obstruction due to progressive involvement of the nose, necessitating surgical intervention. The clinical and pathological aspects of the disease, and the differential diagnosis (ie, congenital generalized fibromatosis, Von Recklinghausen disease, Winchester syndrome) are discussed.

Key Words: Hard nodules; Juvenile hyaline fibromatosis; Tissue expansion

\section{Fibromatose hyaline juvénile : un recul clinique de 47 ans}

\begin{abstract}
RÉSUMÉ : Environ 40 cas de fibromatose hyaline juvénile sont actuellement recensés. Cette affection n'a pas encore été décrite dans la littérature de chirurgie plastique. Le présent article décrit un cas où cette maladie a entraîné une obstruction nasale complète due à un envahissement progressif du nez, nécessitant alors une intervention chirurgicale. Les aspects pathologiques et cliniques de la maladie, et les diagnostics différentiels (soit la fibromatose congénitale généralisée, la maladie de Von Recklinghausen, le syndrome de Winchester) sont discutés.
\end{abstract}

$\mathbf{J}_{\mathrm{h}}^{\mathrm{u}}$ uvenile hyaline fibromatosis is a rare disease whose inheritance follows the autosomal recessive pattern. It was first reported in 1873 by Murray (1). The patient usually presents during infancy with slowly growing cutaneous nodules or plaques, gingival hyperplasia, joint contractures and osteolytic bone lesions (1-4). Consanguinity is present in approximately $50 \%$ of patients (5). The case of a 37-year-old patient whose disease resulted in complete nasal obstruction that necessitated surgical intervention is reported.

\section{CASE PRESENTATION}

A 37-year-old man was first seen in 1954 at five years of age because of convergent concomitant squint and asymptomatic hard nodules that had been appearing since he was two years of age on his scalp, face, arms, hands and knees (Figures 1,2,3). His mother experienced an uneventful term pregnancy and a normal vaginal delivery. Family history re-

Correspondence and reprints: Dr IL Kaddoura, Division of Plastic Surgery, Department of Surgery, American University Medical Center, Beirut, Lebanon PO Box 113-6044. Telephone 961-1-351800,

fax961-1-346946, e-mail imadkaddoura@hotmail.com vealed two normal elder brothers and one sister; however, his grandparents were consanguinous.

Aside from the seven hard, nonpedunculated nodules, physical examination did not reveal gingival hyperplasia, joint swelling or contractures. X-rays of the chest, skull and lower extremities were normal, but x-rays of the upper extremities revealed a slight delay in the maturation of the metacarpal bones for the age of the patient, with three centres of ossification instead of the usual four centres. Hematology and chemistry studies were normal. The seven lesions were excised, and the diagnosis was labeled as Von Recklinghausen disease.

Over the next 34 years, the patient had numerous surgical excisions for new disfiguring nodules that continued to appear, especially on the head, neck and both hands. This resulted in full grip difficulties due to diffuse involvement of the fingers and palm, but no clinical or radiological evidence of joint involvement (Figure 4).

The patient finally presented to the authors because of external nasal obstruction that resulted from repeated nasal surgeries for previous lesions (Figure 5). Intranasal examination revealed complete obstruction due to overlying skin involve- 


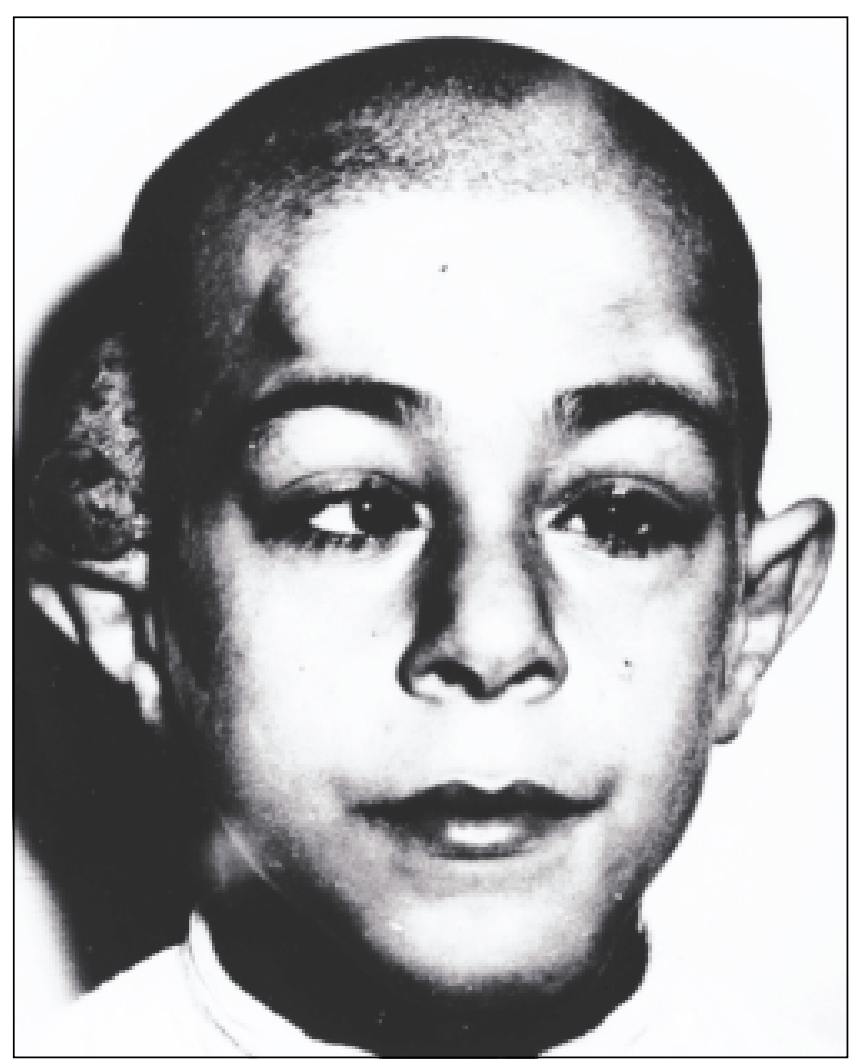

Figure 1) Patient with juvenile hyaline fibromatosis. Facial view at five years of age with the characteristic cutaneous and subcutaneous nodules

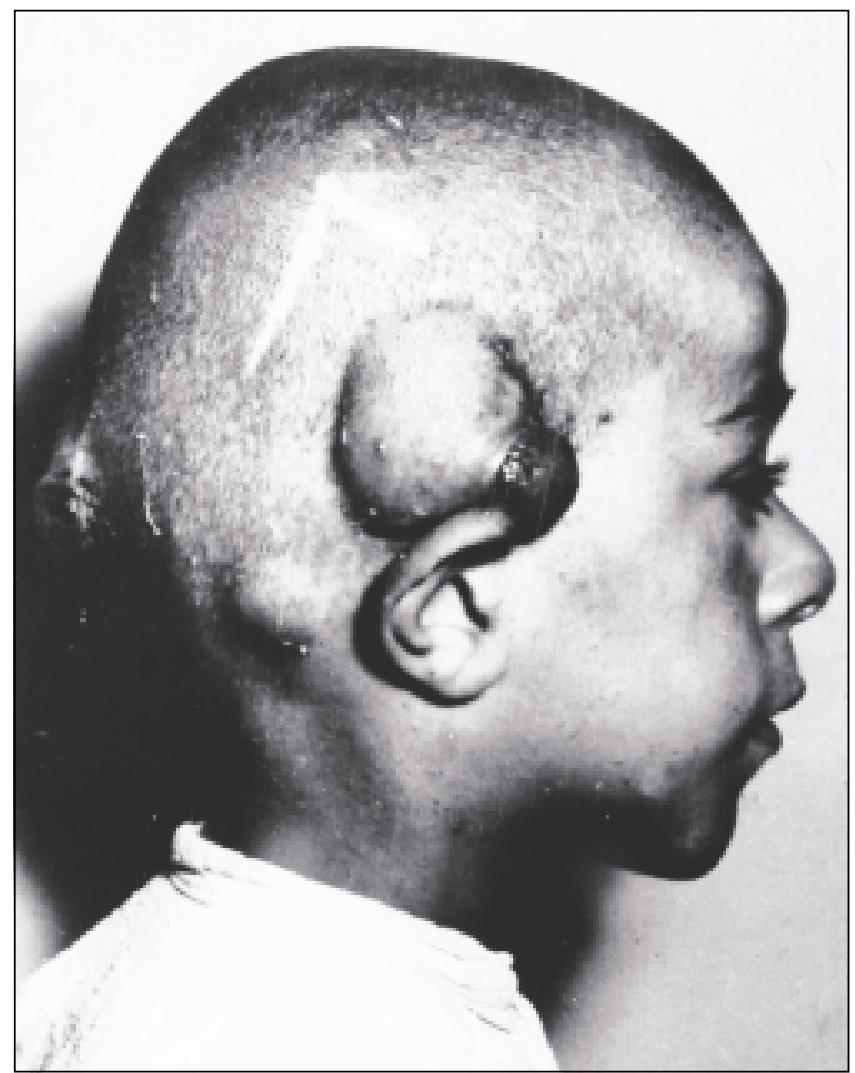

Figure 2) Lateral view showing different stages of the disease with scars of previous excisions

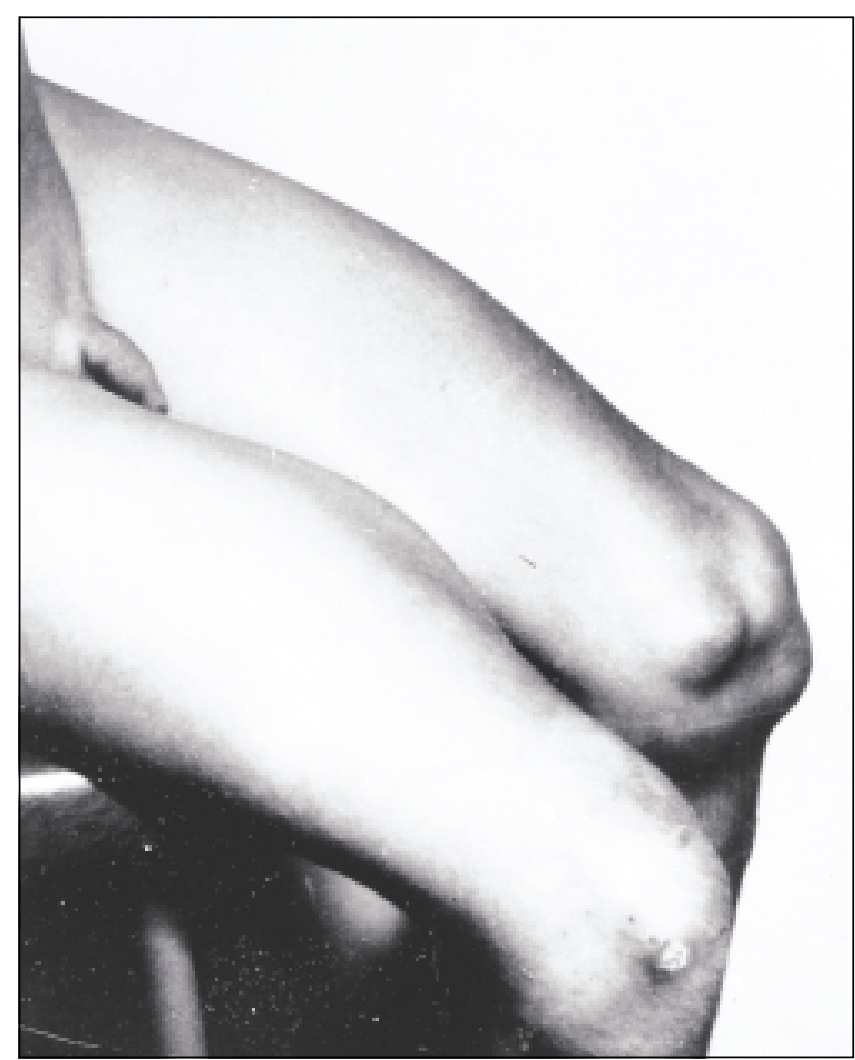

Figure 3) Bilateral lower extremity nodules of the same patient at 10 years of age

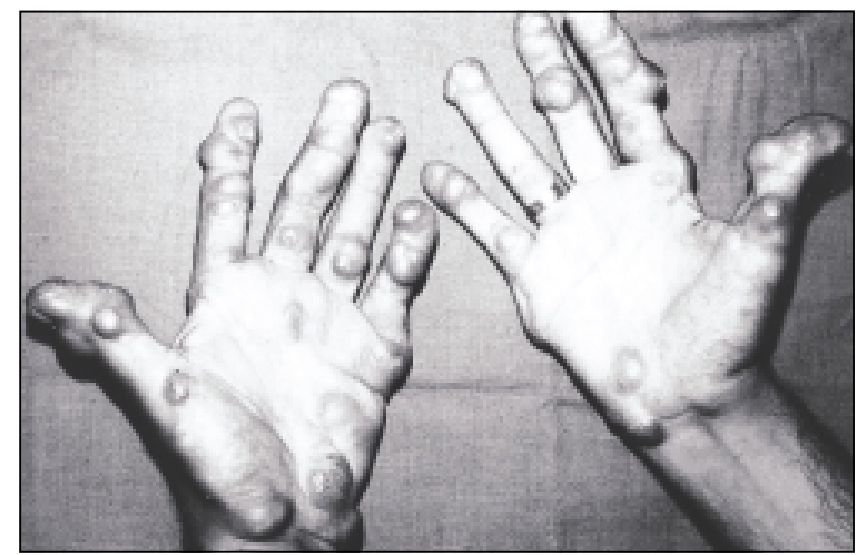

Figure 4) Bilateral hand involvement of the same patient at 37 years of age

ment by the lesions and previous scars. Although the forehead was involved, with three previous small excisions, the decision was made to insert a tissue expander and develop sufficient expanded pedicled skin based on the supra orbital and supra trochlear vessels over three months to perform total soft tissue reconstruction of the nasal skin (Figures 6,7,8). Two weeks later, the patient was breathing normally again through his nose. Following his surgery, and for the next 10 years, the patient did not develop new lesions on his transferred forehead tissue. The patient died at the age of 47 years, 


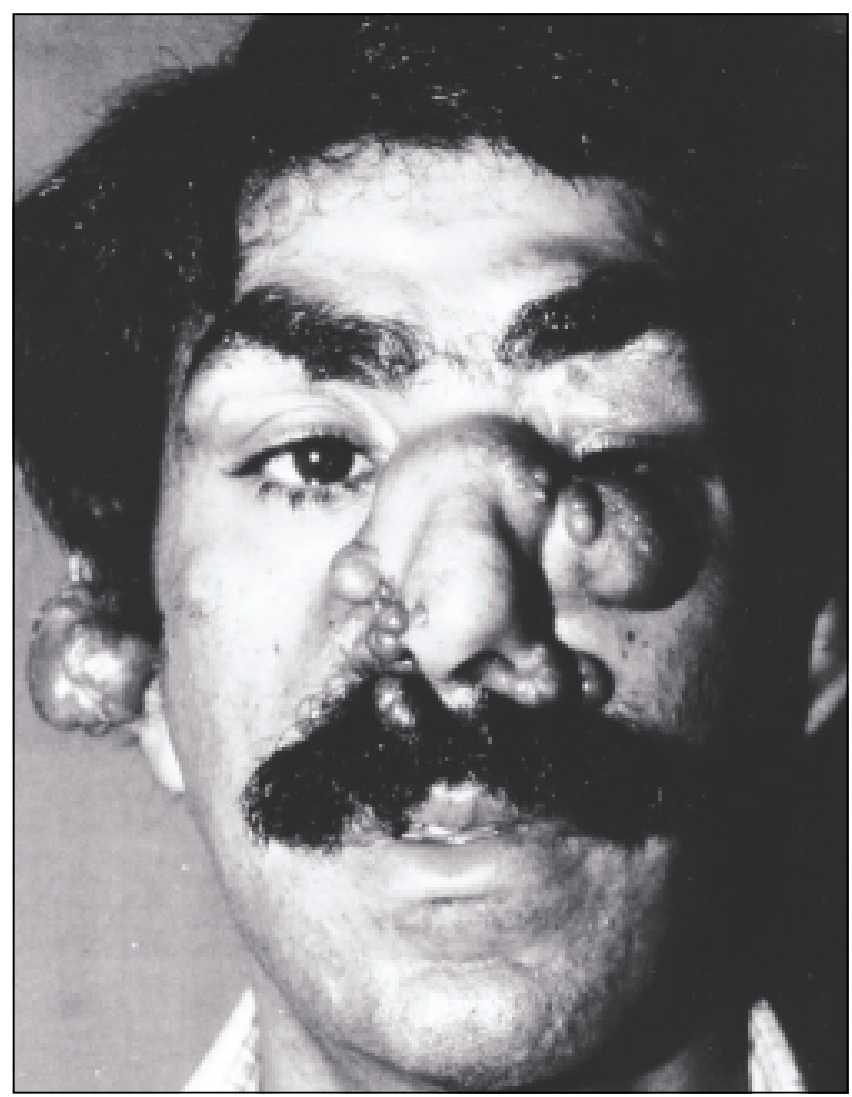

Figure 5) Facial presentation of the same patient at 37 years of age with extensive involvement of nasal skin

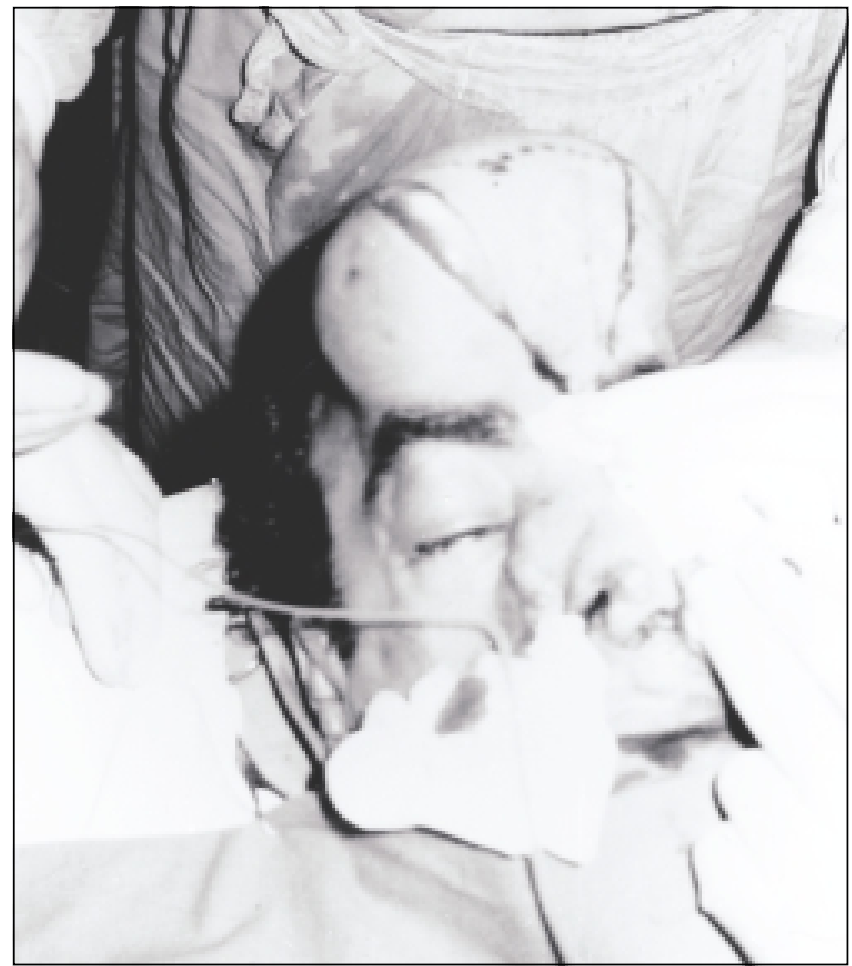

Figure 6) Intraoperative view of the fully expanded forehead with pedicled flap design

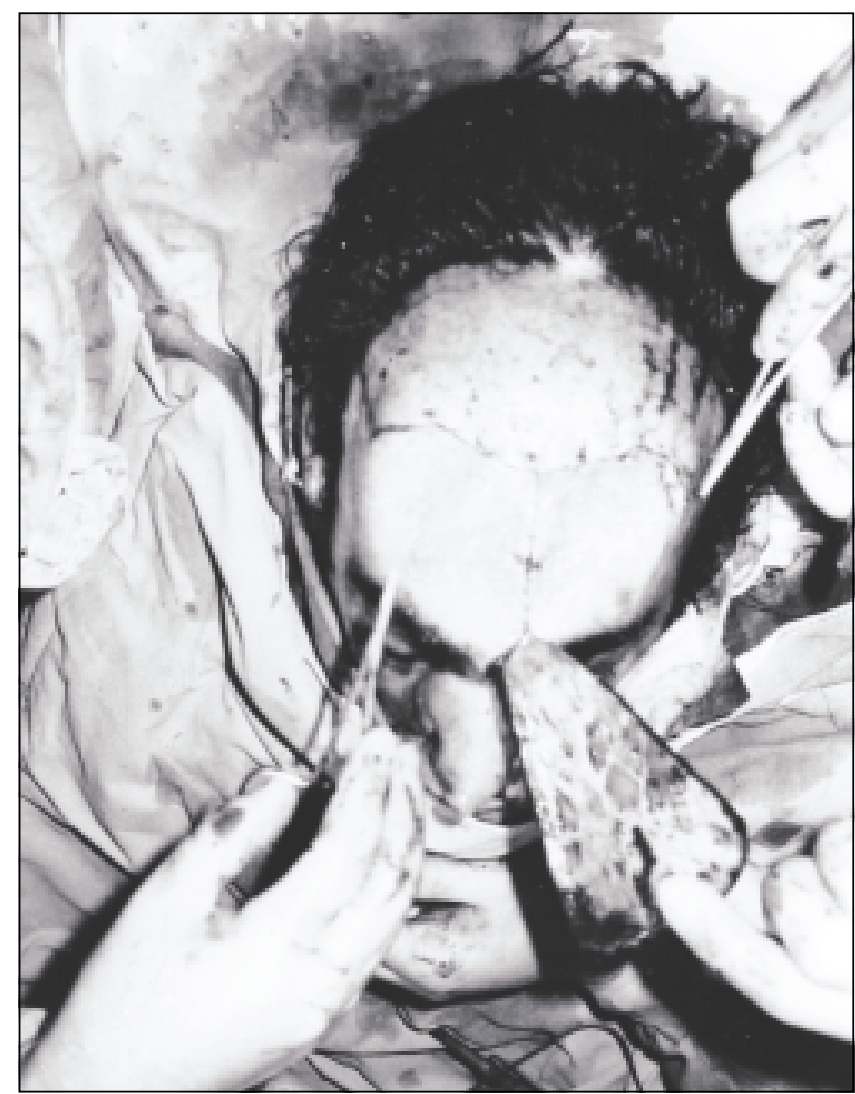

Figure 7) Transferring the expanded forehead flap with primary closure of the donor site

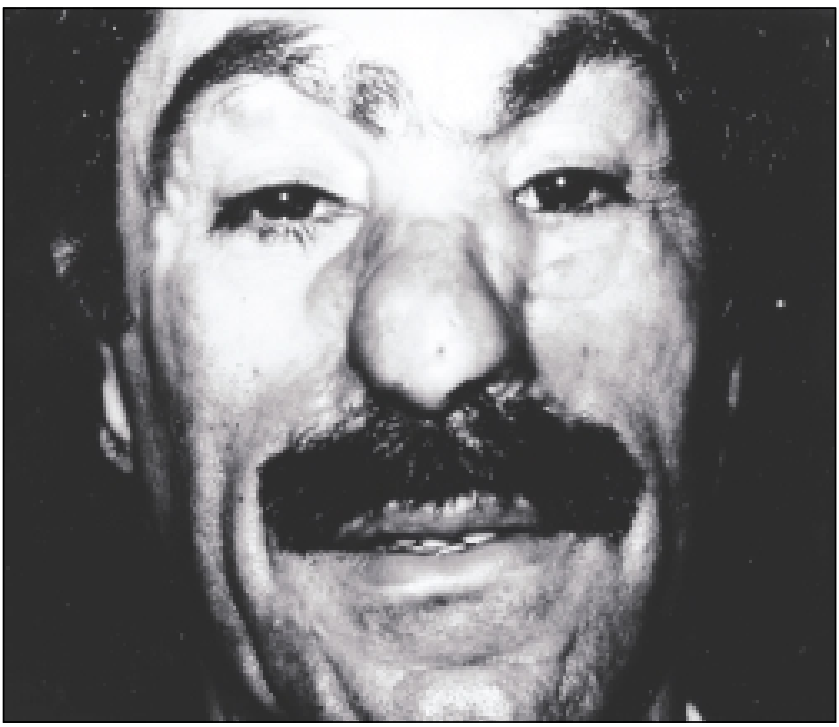

Figure 8) Eight months following the nasal reconstruction

one month after undergoing a hepatectomy for a gall bladder adenocarcinoma that was coincidental with cholelithiasis. The same gall bladder pathology ended the life of his father at 74 years of age. 


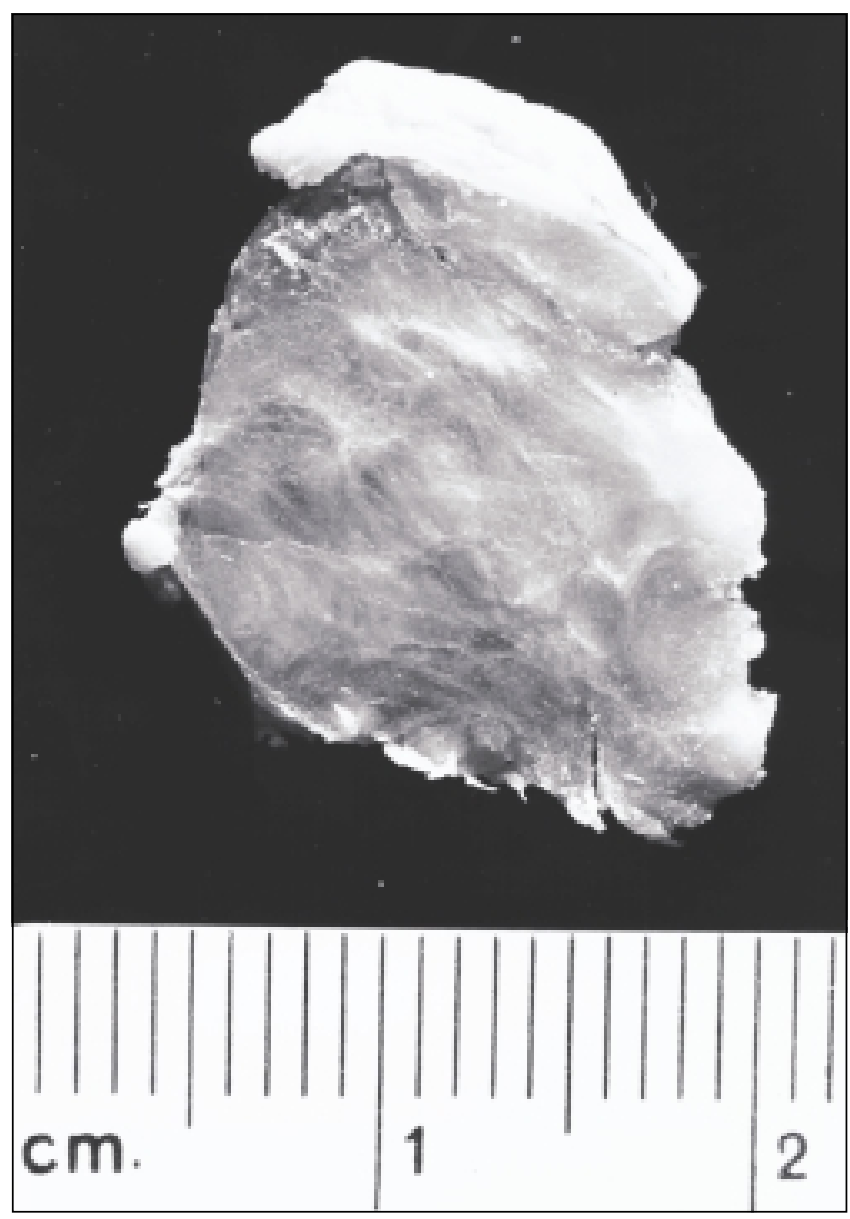

Figure 9) Gross skin nodule showing a broad based, poorly delineated, hard translucent lesion

\section{PATHOLOGICAL FINDINGS}

During his lifetime, the patient had approximately 20 lesions resected, mostly from the head, shoulders and upper extremities. These lesions were poorly delineated, hard, broad- based, homogenous and translucent (Figure 9). Histologically, they consisted of subcutaneous nodules composed of hyalinized fibrous tissue, usually with low cellularity (Figure 10). The overlying epidermis was thinned or ulcerated. The cells were embedded in an amorphous eosinophilic substance. The collagen fibres were densely packed but otherwise unremarkable. There was no atypia or mitosis. The trichrome stain showed a green colouration of the hyaline area. Congo red stain was negative for amyloidosis. Elastic stain was negative in the lesion. Antoni A or Antoni B areas, palissading, or Verocay bodies were not noticed. No inflammation, necrosis or any increased vascularity was present. Immunohistochemically, actin, S100 and neurofilament stains were negative.

\section{DISCUSSION}

Since its original description by Murray in 1873, approximately 40 patients with juvenile hyaline fibromatosis have been described in the literature (1-34). In 1967, Drescher et

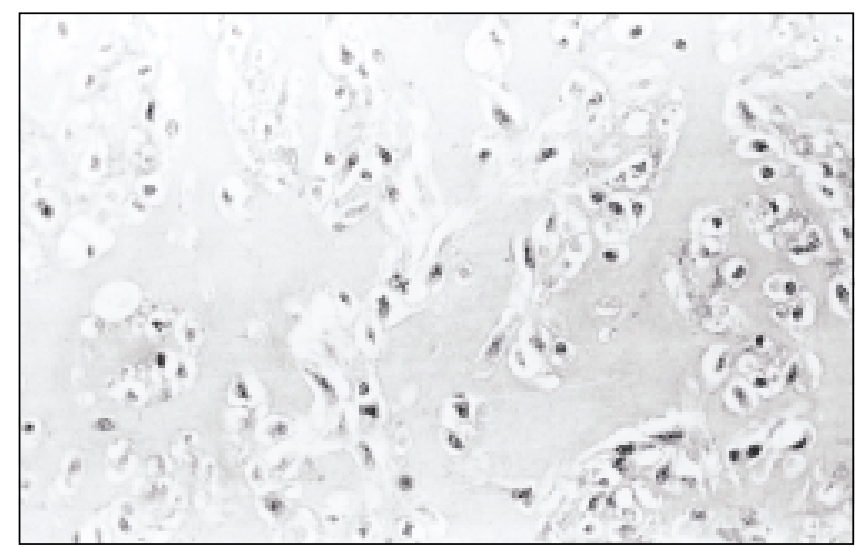

Figure 10) Histology of skin nodule showing the characteristic cellularity and hyalinized ground substance

al (3) were the first to name the disease after reporting it in two siblings. The majority of patients (greater than 25) were reported in the dermatology $(2,4-14)$ and pediatric literature (25-30). This is because the disease usually manifests itself early in childhood (ie, birth to six years of age) with cutaneous and subcutaneous lesions (5). Nodules or pearly papules associated with gingival enlargement, joint contractures and osteolytic defects of the bones are the most common clinical findings (5). It is associated with a $50 \%$ positive family history of consanguinity $(2,5)$. Atypical presentations are common $(3,5,24)$. In patients with gingival hyperplasia, the disease may interfere with normal feeding and intubation for surgical interventions $(16,22,29,34)$. A high percentage of patients have painful and debilitating flexion contractures of small and large joints that cause generalized stiffness and marked deformation of the affected areas $(29,32)$. Our patient did not demonstrate gingival hypertrophy, mental retardation or flexion contractures, although his hands were grossly involved. Radiological examination revealed only localized osteolytic lesions in the distal phalanges of the hand, with normal small and large joints.

Recent literature has identified the differential diagnosis of juvenile hyaline fibromatosis from other similar entities such as congenital generalized fibromatosis, Von Recklinghausen disease and Winchester syndrome $(5,19,33)$. Table 1 shows that the constant stigma of juvenile hyaline fibromatosis are the characteristic hard cutaneous and subcutaneous nodules, which begin to appear in infancy and early childhood in a patient with normal mental development. These broad-based or pear-like hard nodules of early onset should be differentiated from the soft to firm, usually pedunculated skin lesions of Von Recklinghausen disease, which are commonly associated with café au lait spots or freckles in early adulthood (19).

Although the progressively destructive nature of the disease leads to middle age debilitation, very few articles address the histories of these severely handicapped patients on follow-up. In 1983, Finlay et al (11) reported on the clinical progress of four patients who suffered from a continuous pro- 
TABLE 1

Usual clinical and radiological presentations of the literature reviewed

\begin{tabular}{|c|c|c|c|c|}
\hline Clinical findings & Juvenile hyaline fibromatosis & $\begin{array}{l}\text { Von Recklinghausen } \\
\text { disease }\end{array}$ & $\begin{array}{l}\text { Congenital generalized } \\
\text { fibromatosis }\end{array}$ & Winchester syndrome \\
\hline Time of appearence & Two months to four years & $\begin{array}{l}\text { Late childhood and } \\
\text { adulthood }\end{array}$ & At birth & Early after birth \\
\hline Consanguinity & Positive in $50 \%$ of patients & Suggested & Common & $\begin{array}{l}\text { Siblings of consanguineous } \\
\text { marriages }\end{array}$ \\
\hline Skin lesion - Form & $\begin{array}{l}\text { Hard cutaneous and subcutane- } \\
\text { ous nodules, tumours are } \\
\text { broad-based or pear-like }\end{array}$ & $\begin{array}{l}\text { Soft to firm, usually } \\
\text { pedunculated }\end{array}$ & $\begin{array}{l}\text { Widely distributed } \\
\text { subcutaneous nodules }\end{array}$ & $\begin{array}{l}\text { Thickened raised skin } \\
\text { areas with } \\
\text { hypertrichosis }\end{array}$ \\
\hline Pigmentation & Absent & Café au lait spots & $*$ & Hyperpigmentation \\
\hline Gingival involvement & $\begin{array}{l}\text { Present in majority of patients } \\
\text { reported }\end{array}$ & $*$ & $*$ & Gum hypertrophy \\
\hline Viceral involvement & Absent & $*$ & $\begin{array}{l}\text { Widespread (ie, larynx, } \\
\text { intestine, lungs, heart, } \\
\text { muscle) }\end{array}$ & $*$ \\
\hline$X$-ray findings & Lytic lesions in long and flat bones & * & * & $\begin{array}{l}\text { Osteoporosis, erosion of } \\
\text { metacarpal bones, } \\
\text { progressive resorption } \\
\text { of carpal bones }\end{array}$ \\
\hline Mental involvement & Normal & Usually normal & $*$ & $*$ \\
\hline $\begin{array}{l}\text { Natural history of the } \\
\text { disease }\end{array}$ & $\begin{array}{l}\text { Characteristic progressive skin } \\
\text { involvement }\end{array}$ & Normal life expectancy & Usually die early in life & $\begin{array}{l}\text { Die at birth or shortly after } \\
\text { progressive debilitation } \\
\text { (ie, lung involvement) }\end{array}$ \\
\hline Causal associations & $\begin{array}{l}\text { Myopathy, hypertrichosis, } \\
\text { gastrointestinal reflux, } \\
\text { hypochromic anemia }\end{array}$ & $\begin{array}{l}\text { Meningioma glioma } \\
\text { acoustic neuroma }\end{array}$ & $*$ & $*$ \\
\hline
\end{tabular}

*No data could be found in the literature

gression of the disease with ulcerating skin lesions, progressive joint contractures and immobilization that was originally reported by Puretic et al (3), Ishikawa and Hori (35), Kitano et al (4) and Kitano (7). All of these patients were still alive in 1985 at 33, 22, 21 and 16 years of age with severe physical disabilities and normal mental status. In 1985, Remberger et al (15) reported the case of a similar patient who died at 26 years of age. It is, thus, highly probable that our patient, who died of an unrelated cause (adenocarcinoma of the gall bladder), is the oldest reported patient.

Histologically, the lesions of juvenile hyaline fibromatosis reveal a uniformly dense growth of collagen (Figures 9,10 ). This differentiates them from lesions of neurofibromatosis, which exhibit loose areas and palissading, and from other lesions that show mucoid change of the collagen. Moreover, the classic trichrome stain demonstrates the presence of collagen rather than smooth muscle. The immunohistochemical stains negate the presence of smooth muscle, neural tissue or cartilagenous tissue. These findings confirm those reported earlier using other techniques (15). Transmission electron microscopy showed a prominent Golgi apparatus in the fibroblast-like cells filled by aggregates of microfilaments. These aggregates can also be seen in the ground substance immunofluorescense demonstrated by the presence of collagen types I and III. Collagen type II, associated with cartilage, could not be detected. The biochemical analysis also revealed collagen types I and III and, in one instance, chondroitin. Accumulated data indicate that the hyaline material is caused by an abnormality of collagen alignment and faulty synthesis of ground substance.

\section{CONCLUSIONS}

Few descriptions of patients with juvenile hyaline fibromatosis are published in the dermatology, pediatric, pathology, radiology, anesthesia and other nonplastic surgery literature. This report describes our experience with the management of a very rare mutilating disease that is not encountered by many plastic surgeons. Gall bladder adenocarcinoma, which led to the deaths of our patient at 47 years of age and his father at 74 years of age, respectively, was most likely coincidental. To our knowledge, this patient is the oldest reported case of juvenile hyaline fibromatosis in the medical literature with the longest follow-up. It is unknown to us why the previously involved forehead skin that was used in nasal reconstruction did not develop lesions for 10 years after its transfer. 


\section{REFERENCES}

1. Murray J. On three peculiar cases of molluscum fibrosum in children. Med Chir Trans 1873;38:235-53.

2. Puretic S, Puretic B, Fiser-Herman M, Adamicic M. A unique form of mesenchymal dysplasia. Br J Dermatol 1962;74:8-19.

3. Drescher E, Woyke S, Markiewicz C, Tegi S. Juvenile fibromatosis in siblings (fibromatosis hyalinica multiplex juvenilis). J Pediatr Surg 1967;2:427-30.

4. Kitano Y, Horiki M, Aoki T, Sagami S. Two cases of juvenile hyaline fibromatosis. Some histological, electron microscopic, and tissue culture observations. Arch Dermatol 1972;106:877-83.

5. Gilaberte Y, Gonzalez-Mediero I, Lopez Barrantes V, Zambrano A. Juvenile hyaline fibromatosis with skull-encephalic anomalies: a case report and review of the literature. Dermatology 1993;187:144-8.

6. Gutierrez G, Zambrano V, Garcia F, Martin F, Ospina J, Camargo H. Fibromatosis hialinica multiple juvenil: a proposito de un caso. Med Cutan Ibero Lat Am 1973;3:283-6.

7. Kitano Y. Juvenile hyalin fibromatosis. Arch Dermatol 1976;112:86-8.

8. Costa OG, Costa PU. Fibromatosis hialina juvenil. Med Cutan Ibero Lat Am 1975;3:331-40.

9. Gianotti F, Ermacora E, Magrini U. Fibromatosis hyaline juvenile. Ann Dermatol Venereol 1977;104:152-3.

10. Atherton DJ, Lake BD, Wells RS. Juvenile hyaline fibromatosis. Br J Dermatol 1981;19(Suppl):61-3.

11. Finlay AY, Ferguson SD, Holt PJA. Juvenile hyaline fibromatosis. Br J Dermatol 1983;108:609-16.

12. Poiares Baptista A, Fonseca N, Gancalo S. Fibromatose hyaline juvenile. Ann Dermatol Venereol 1983;110:751-2.

13. Yesudian P, Janaki VR, Thambiah AS. Juvenile hyaline fibromatosis. Int J Dermatol 1984;23:619-20.

14. Quintal D, Jackson R. Juvenile hyaline fibromatosis. A 15-year follow-up. Arch Dermatol 1985;121:1062-3.

15. Remberger K, Krieg T, Kunze D, Weinmann HM, Hubner C. Fibromatosis hyalinica multiplex (juvenile hyaline fibromatosis). Light microscopic, electron microscopic, immunohistochemical, and biochemical findings. Cancer 1985;56:614-24.

16. Sciubba JJ, Niebloom T. Juvenile hyaline fibromatosis (Murray-Puretic-Drescher syndrome): oral and systemic findings in siblings. Oral Surg Oral Med Oral Pathol 1986;62:397-409.

17. Camarasa JG, Moreno A. Juvenile hyaline fibromatosis. J Am Acad Dermatol 1987;16:881-3.

18. Chitale AR, Murthy AK, Maniar JK. Juvenile hyaline fibromatosis. Ultrastruct Pathol 1987;11:771-5.
19. Fayad MN, Yacoub A, Salman S, Khudr A, Der Kaloustian VM Juvenile hyaline fibromatosis: two new patients and review of the literature. Am J Med Genet 1987;26:123-31.

20. Kan AE, Rogers M. Juvenile hyaline fibromatosis: an expanded clinicopathologic spectrum. Pediatr Dermatol 1989;6:68-75.

21. O'Neill DB, Kasser JR. Juvenile hyaline fibromatosis. A case report and review of musculoskeletal manifestations. J Bone Joint Surg [Am] 1989;71:941-4.

22. Vaughn GC, Kaplan RF, Tieche S, Downs JB. Juvenile hyaline fibromatosis: anesthetic management. Anesthesiology 1990;72:201-3.

23. Ramos A, Martins-Guedes AC. Juvenile hyaline fibromatosis Case report and review. 18th World Congress on Dermatology. New York, June 12 to 18, 1992. (Abst 187)

24. Woyke S, Domagala W, Olszewski W. Ultrastructure of a fibromatosis hyalinica multiplex juvenilis. Cancer 1970;26:1157-68.

25. Dunger DB, Dicks-Mireaux C, O’Driscoll P, Lake B, Shaw DG, Grant DB. Two cases of Winchester syndrome: with increased urinary oligosaccharide excretion. Eur J Pediatr 1987;146:615-9.

26. Moy LS, Moy RL, Matsuoka LY, Ohta A, Uitto J. Lipoid proteinosis: ultrastructural and biochemical studies. J Am Acad Dermatol 1987;16:1193-201.

27. Yarom A, Rennebohm M, Levinson JE. Infantile multisystem inflammatory disease: a specific syndrome? J Pediatr 1985;106:390-6.

28. Glover MT, Lake BD, Atherton DJ. Infantile systemic hyalinosis: newly recognized disorder of collagen? Pediatrics 1991;87:228-34

29. Bedford CD, Sills JA, Sommelet-Olive D, Boman F, Beltramo F, Cornu G. Juvenile hyaline fibromatosis: a report of two severe cases. J Pediatr 1991;119:404-10.

30. Iwata S, Horiuchi R, Maeda H, Ishikawa H. Systemic hyalinosis or juvenile hyaline fibromatosis. Ultrastructural and biochemical study of cultured skin fibroblasts. Arch Dermatol Res 1980;267:115-21.

31. Stringer DA, Mall CM. Juvenile hyaline fibromatosis. Br J Radiol 1981;54:473-8

32. Suzuki S, Kasahara Y, Seta Y, et al. Juvenile hyaline fibromatosis. J Bone Joint Surg 1992;74:290-3.

33. Jacyk WK, Wentzel LF. Juvenile hyaline fibromatosis in two South African black children. Int J Dermatol 1996;35:740-2.

34. Norman B, Soni N, Madden N. Anesthesia and juvenile hyaline fibromatosis. Br J Anesth 1996;76:163-6.

35. Ishikawa H, Hori Y. Systenatisierte hyalinose in Zusammenhangmit epidermolysis bullosa polydystrophica und hyalinosis cutis et mucosae. Arch Klin Exp Dermatol 1964;218:30-51. 